\title{
Physicochemical components of Astragalus membranaceus fermented with mushroom mycelia
}

\author{
Yeon-Jeong Jang ${ }^{1}$, Yun-Hye Lee ${ }^{2}$, Chan-Jung Lee ${ }^{3}$, Jae-Hyeon Kim${ }^{1}$, Eun-Ju Kim ${ }^{1}$, \\ Soo-Jeong $\mathrm{Ji}^{1}$, Shin-Young Park ${ }^{1 *}$ \\ ${ }^{1}$ Fermentated Food Science Division, National Institute of Agricultural Sciences, RDA, Wanju 55365, Korea \\ ${ }^{2}$ Mushroom Research Institute, Gyeonggi Province, ARES, Gwang-ju 12805, Korea \\ ${ }^{3}$ Mushroom Research Division, National Institute of Horticultural and Herbal Science, RDA, Eumseong 27709, Korea
}

\section{담자균 균사체가 배양된 황기의 이화학적 성분분석}

\author{
장연정 ${ }^{1} \cdot$ 이윤혜 ${ }^{2} \cdot$ 이찬중 ${ }^{3} \cdot$ 김 재현 $^{1} \cdot$ 김은주 $^{1} \cdot$ 지수정 $^{1} \cdot$ 박신영 $^{1 *}$ \\ ${ }^{1}$ 농촌진흥청 국립농업과학원 농식품자원부 발효식품과, ${ }^{2}$ 경기도농업기술원 버섯연구소, \\ 3농촌진흥청 국립원예특작과학원 버섯과
}

\begin{abstract}
This study analyzed the physicochemical characteristics of Astragalus membranaceus (AM) fermented with seven different mushroom mycelia. Physicochemical characteristics, such as contents of moisture, $\mathrm{pH}$, total reducing sugars, free sugar, and isoflavonoid, were investigated. The moisture content was increased in most of the samples. The $\mathrm{pH}$ values of $\mathrm{AM}$ fermented with Phellinus linteus and Flammulina velutipes were increased, while the $\mathrm{pH}$ of other samples were similar to that of non-fermented AM. The reducing sugar content was in the range of 211.69 391.74 $\mathrm{mg} / 100 \mathrm{~g}$. The extraction yield using water was higher than that when extracted with $80 \%$ ethanol. The free sugar content was increased through fermentation with mushroom mycelia. However, the glucose contents of the $80 \%$ ethanol and water extracts were decreased. Finally, the calycosin and formononetin contents in $80 \%$ ethanol and water extracts of AM fermented with Phellinus linteus were $2,549.24 \mathrm{mg} / \mathrm{g}$, and $827.66 \mathrm{mg} / \mathrm{g}$ for calycosin, and $1,366.69 \mathrm{mg} / \mathrm{g}$ and $221.28 \mathrm{mg} / \mathrm{g}$ for formononetin, respectively. These results suggest that fermentation with mushroom mycelia could be used to increase the bioactivity of AM. The mycelium-fermented AM might be a valuable source of functional material and edible resource for industry.
\end{abstract}

Key words : mushroom mycelium, Astragalus membranaceus, physicochemical components

\section{서 론}

최근 식물 유래 생리활성물질은 암을 비롯한 심장병, 고 혈압, 당뇨 및 백내장 등 성인병 및 대사증후군을 예방하는 기능성소재로서 크게 각광을 받고 있으며, 국내외적으로 천연물로부터 식물 화학물질을 개발하려는 연구가 활발히

*Corresponding author. E-mail : soyoenj@korea.kr Phone : 82-63-238-3625, Fax : 82-63-238-3843

Received 9 September 2015; Revised 26 October 2015; Accepted 1 January 2016.

Copyright (c) The Korean Society of Food Preservation. All rights reserved.
진행되고 있다. 질병의 치료방법으로서 의학적인 방법이 주된 치료방법이었지만, 특정식품 섭취로 인해 만성질환의 발생을 억제 또는 지연시킨다는 연구보고 결과 $(1,2)$ 로 인해 만성질환의 치료방법으로써 식이 요법의 중요성이 대두되 고 있으며 이러한 추세에 따른 새로운 식품소재와 더불어 가공식품 등 개발을 위한 자원으로서 약용식물에 대한 더 많은 연구가 필요하다.

황기(Astragalus membranaceus)는 기운을 보하는 대표적 인 한약재로 성질은 따뜻하고 맛은 달며 한방에서 지한(⿻上丨 汗), 이뇨, 강장, 혈압강하 등의 목적으로 사용되고 있다. 약리실험 연구에서는 항염, 이뇨, 강장(3), 혈당강하(4), 면 역증강, 항종양, 항바이러스 작용 등이 있는 것으로 밝혀졌 
다(5,6). 또한, 황기는 간 기능을 보호하는 물질을 함유하고 있을 뿐 아니라, isoflavone성분을 함유하고 있어 항산화 기능이 우수하며, 항당뇨 기능이 있다고 보고 된 바 있다(7).

또한, 버섯류의 경우에도 항암 및 면역기능 증강, 만성위 염, 신체허약 등(8)에 여러 가지 높은 생리활성 효능이 다양 한 연구를 통해 밝혀진바 있으며, 버섯 균사체는 자실체와 유사한 생리적 기능을 가지는 것으로 밝혀져(9) 식용 또는 의료용으로 복용 시 독성 및 부작용이 나타나지 않으므로 (10-12) 기능성 자원으로서의 활용이 기대된다. 이러한 균 사체를 식용이 가능한 곡류나 약용식물 등의 고체재료에 배양하면 별도의 추출 공정 없이 바로 이용하는 것이 가능 하며 $(2,13)$, 최근에는 미생물 이용을 통한 한약재의 효능 증가 및 새로운 효능을 도출하는 연구가 활발히 진행되고 있는데 예를 들어 유산균 발효한 자음강화탕 성분의 생물전 환으로 효능이 증가된 자음강화탕 개발(14) 및 기호성 및 품질이 증진된 백련잎 발효차 개발을 위해 동충화초 균사체 배양한 백련잎차의 품질특성(15)등 의 연구가 보고되었다. 허나 현재까지 담자균 이용하여 약용식물의 효능증가 및 식품소재로 이용한 사례 및 연구가 미비한 실정이다.

따라서, 본 연구에서 담자균 균사체를 황기에 배양하여 이용성 및 기능성을 증진시킨 식품 개발 및 그밖에 다양한 식품첨가제 등의 용도로 쓰일 수 있는 소재를 개발하기 위한 연구의 일환으로 기초연구를 실시하였다.

\section{재료 및 방법}

\section{실험재료}

본 실험에 사용된 균주는 국립원예특작과학원 버섯과에 서 분양받은 상황버섯(Phellinus linteus), 말굽버섯(Fomes fomentarius), 영지버섯(Ganoderma lucidum), 큰 느타리버 섯(pleurotus eryngii), 팽이버섯(Flammulina velutipes), 표고 버섯(Lentinus edodes)균주와 경기도농업기술원 버섯연구 소에서 분양받은 곤지 7호 버섯(Pleurotus ostreatus Gonji-7ho) 균주를 분양받아 사용하였으며, 담자균 배양용 약재 황기(Astragalus membranaceus)는 충북 제천산 3년근 으로(Hanbangchon, Korea)에서 구입하여 사용하였다.

\section{균주별 배지 및 배양조건}

균의 보존용 배지로는 영지버섯(G. lucidum), 큰 느타리 버섯(P. eryngii), 팽이버섯( $F$. velu-tipes), 표고버섯 $(L$. edodes), 곤지 7호( $P$. ostreatus Gonji-7ho)는 potato dextrose $\operatorname{agar}(\mathrm{PDA}, \mathrm{Difco}$, Detroit, USA)배지, 상황버섯(P. linteus), 말굽버섯(F. fomentarius)은 YPD-Agar(Difco, Detroit, USA) 배지를 사용하여, $25^{\circ} \mathrm{C}$ 에서 15 일간 평판 배양한 다음 접종 원으로 사용하였다.
담자균 배양 황기 제조

황기 $5 \mathrm{~kg}$ 을 톱밥형태로 분쇄한 뒤 황기 및 미강을 $4: 1$ 비율로 미강 $1.25 \mathrm{~kg}$ 첨가하고, $2 \mathrm{~L}$ 증류수를 가해 혼합한 후 각 $300 \mathrm{~g}$ 씩 톱밥종균 배양병에 병입 하고, autogclave (Vision Scientific, Co., Ltd., Korea)에서 $120^{\circ} \mathrm{C}, 40$ 분 멸균시 킨 다음, 각 배양병당 상황버섯(P. linteus), 말굽버섯 $(F$. fomentarius), 영지버섯(G. lucidum), 큰 느타리버섯(P. eryngii), 팽이버섯( $F$. velutipes), 표고버섯(L. edodes) 곤지 7호 버섯(P. ostreatus Gonji-7ho)등 7종의 균주를 접종하여 $25^{\circ} \mathrm{C}$ 온도의 incubater(VS-1203PFHLN, Vision Scientific, Co., Ltd., Korea)에서 30일간 배양하며 발효시켰다. 담자균 배양한 황기는 $-80^{\circ} \mathrm{C}$ 초저온냉동기(deep freezer, Ilsin BioBase Co., Ltd., Korea)에서 24시간 동결시킨 후 동결건 조기(freeze dryer, Ilsin BioBase Co., Ltd., Korea )에서 72시 간 동결 건조시킨 것을 마쇄하여 시료로 사용하였다.

담자균 배양 황기의 수분 함량 및 $\mathrm{pH}$ 측정

담자균 배양 황기의 수분 함량은 적외선 수분 측정기 (MS-70, AND Co., Japan)를 이용하여 측정하였으며, $\mathrm{pH}$ 는 시료 $2 \mathrm{~g}$ 을 칭량하여 $8 \mathrm{~mL}$ 의 증류수를 가하여 균질화한 후 $3,000 \mathrm{rpm}$ 에서 15 분간 원심분리한 후 상등액을 취하여 $\mathrm{pH}$ meter(HM-30P, DKK-TOA, Japan)로 측정하였다. 총 산 도는 $\mathrm{pH}$ 측정의 시료와 동일한 시료를 $3,000 \mathrm{rpm}$ 에서 15 분 간 원심분리한 후 시료액 $0.1 \mathrm{~mL}$ 에 $0.9 \mathrm{~mL}$ 의 증류수를 가하여 $10 \mathrm{~mL}$ 로 정용한 후, 지시약 $0.05 \%$ phenolphthalein을 사용하여 $0.1 \mathrm{~N} \mathrm{NaOH}$ 로 $\mathrm{pH}$ 8.3에 도달 할 때까지 적정하였 으며, 적정에 소비된 $\mathrm{NaOH}$ 소비량을 이용하여 acetic aicd 함량(\%)으로 환산하여 총산 함량을 표시하였다. 실험은 3 회 반복하였으며 결과는 평균값표준편차로 나타내었다.

\section{환원당 측정}

환원당은 dinitrosalicylic acid(DNS)법(16)에 따라 추출여 액 $1 \mathrm{~mL}$ 에 DNS reagent $1 \mathrm{~mL}$ 을 가하여 15 분간 끓인 다음, 냉각한 후 증류수 $3 \mathrm{~mL}$ 을 첨가하여 UV-visible spectrophoto meter를 이용하여 $546 \mathrm{~nm}$ 의 파장에서 흡광도를 측정하였 다. 이때 당의 정량은 glucose를 표준물질로 사용하여 표준 곡선으로부터 환산하여 함량을 산출 하였다.

\section{추출물 제조 및 추출수율 측정}

추출물 제조는 담자균 배양 황기를 동결건조 한 것을 사용하여 $80 \%$ 에탄올 추출물 및 열수추출물을 제조하였다. $80 \%$ 에탄올 추출물의 제조는 다음과 같다. 각 동결건조 된 배양물 $5 \mathrm{~g}$ 에 $80 \%$ 에탄올 수용액 $100 \mathrm{~mL}$ 씩 가하여 ultrasonicator(Power Sonic 420, 50/60 HZ, 700W, Hwashin Co., Korea)로 1시간 씩 2회 sonication하여 추출한 후 Whatman No. 2 여과지를 이용하여 여과시킨 후, 여과액을 $200 \mathrm{~mL}$ 로 정용하여 rotary vacuum evaporater(BUCHI, 
$\mathrm{USA}$ )를 이용하여 $50^{\circ} \mathrm{C}$ 이하에서 감압·농축하였고, 이를 같은 추출용매로 용해하여 본 실험의 분석용 시료로 사용하 였다. 열수추출물의 제조는 다음과 같다. 각 배양물 $5 \mathrm{~g}$ 에 끓인 증류수 $100 \mathrm{~mL}$ 을 혼합 후 ultrasonication(Power Sonic 420, 50/60 HZ, 700W Hwashin Co., Korea) 장비로 1시간 씩 2회 반복 추출한 후 Whatman No. 2 여과지를 이용하여 여과시킨 후, 여과액을 정용하여 rotary vacuum evaporater (BUCHI, USA)를 이용하여 $50^{\circ} \mathrm{C}$ 이하에서 감압.농축한 뒤, 이를 같은 추출용매로 용해하여 본 실험의 분석용 시료로 사용하였다. 추출수율은 각각의 추출물을 동결 건조시켜서 건조중량을 구한다음 추출물 조제에 사용한 원료 물량에 대한 백분율로 나타내었다.

\section{유리당 분석}

유리당 분석은 HPLC(Waters 2695, waters Co., Miliford, $\mathrm{MA}, \mathrm{USA}$ )를 이용하여 분석하였다. 담자균 배양 황기 추출 물을 희석하여 $0.45 \mu \mathrm{m}$ PVDF membrane filter를 여과한 것을 시험용액으로 하였고, column은 Prevail carbohydrate $\mathrm{ES}(5 \mu \mathrm{m}, 4.6 \times 250 \mathrm{~mm})$ 을 사용하였으며, mobile phase는 acetonitrile : water 혼합액(70:30, v/v), flow rate는 1.0 $\mathrm{mL} / \mathrm{min}$, detector는 ELSD Sigmal(Waters 2424 , Waters Co., Miliford, MA, USA)를 사용하여 분석하였다.

\section{성분 함량분석}

담자균 배양 황기의 $80 \%$ 에탄올 및 열수 추출물 성분 함량분석은 HPLC(Waters 2695)를 이용하여 분석하였다. 각 추출물을 $0.45 \mu \mathrm{m}$ PVDF membrane filter 여과한 것을 시험용액으로 하였고, 분석 조건은 다음과 같다. column은 YMC-Pack Pro C18 $(5 \mu \mathrm{m}, 4.6 \times 250 \mathrm{~mm})$, mobile phase 조성 은 solvent A water: thrifluoro-acetic $\operatorname{acid}(99.5: 0.5, \mathrm{v} / \mathrm{v})$ 와 solvent B Acetonitrile를 사용하였고, flow rate 및 column 온도는 각각 $0.8 \mathrm{~mL} / \mathrm{min}, 30^{\circ} \mathrm{C}$ 로 detector는 photodiode array detector(Waters 2699)를 사용하여 검출하였다. 표준물질은 Calycosin 및 Formononetin을 Sigma-Aldrich Co.로부터 구 입하였고 HPLC에서 나타난 peak area의 3회 반복 평균값을 취한 후 표준물질의 양과 peak area사이의 상관관계를 도출 하여 검량선을 작성하여 계산하였다.

\section{통계처리}

본 실험의 결과는 3 회 반복 실험을 실시한 뒤 평균과 표준편차로 나타내었으며, 각 실험결과에 대한 통계분석은 SAS program(9.2, SAS Inc., Cary, NC, USA)을 이용하여 ANOVA를 실시한 후 Duncan's multiple range test 방법을 사용하여 각 처리구간의 유의적 차이를 검증하였다 $(\mathrm{p}<0.05)$.

\section{결과 및 고찰}

담자균 배양 황기의 수분함량 및 $\mathrm{pH}$ 측정

담자균 7종을 접종하여 30 일간 배양한 황기의 수분함량 및 $\mathrm{pH}$ 를 측정 결과는 Table 1 과 같다. 수분함량은 대조구는 $26.38 \%$ 의 함량을 보였고, 상황버섯 및 큰 느타리 균사체 배양 황기가 각각 $49.58 \%, 38.92 \%$ 로 크게 증가한 함량을 나타내었으며, 전체적으로 균사체 배양 황기의 수분함량은 약 $30 \%$ 이상으로 대조구에 비해 다소 증가하였다. 이는 배양기간이 지남에 따라 균사체의 생장으로 인해 배양물의 수분함량이 꾸준히 증가한 것으로 사료되며, 육안을 통해 황기의 표면이 담자균사에 에워싸여 있는 모습을 보아 균사 체의 생장밀도가 양호한 것을 확인하였다. $\mathrm{pH}$ 는 상황버섯 균사체 배양 황기가 $\mathrm{pH} 6.51$, 팽이버섯 균사체 배양 황기는 $\mathrm{pH}$ 6.41로 증가하였으나, 이외의 배양물의 경우 $\mathrm{pH}$ 5.30 5.61로 전반적으로 대조구와 유사한 결과를 나타내었 으며 거의 차이가 없었다. 이는 담자균 균사의 생장을 보았 을 때 알칼리보다는 $\mathrm{pH} 4 \sim 5$ 범위의 산성에서 배양이 잘된다 는 보고와 일치하였으며, 담자균 Coriolus versicolor 및 Phellinus igniarius 배양액이 배양기간이 지남에 따라 $\mathrm{pH}$ $4 \sim 5$ 에서 $\mathrm{pH} 6$ 이상으로 계속적으로 완만한 상승을 보였다 는 결과(17)와 유사하게 나타났다.

Table 1. $\mathrm{pH}$ values, moisture contents, and reducing sugar contents of Astragalus membranaceus fermented with different mushroom mycelia

\begin{tabular}{lccc}
\hline \multirow{2}{*}{ Strains } & \multicolumn{3}{c}{ Components } \\
\cline { 2 - 4 } & $\begin{array}{c}\text { Moisture contents } \\
(\%)\end{array}$ & $\mathrm{pH}$ & $\begin{array}{c}\text { Reducing sugar } \\
(\mathrm{mg} / 100 \mathrm{~g})\end{array}$ \\
\hline Control & $26.38 \pm 0.01^{\mathrm{h} 1)}$ & $5.56 \pm 0.01^{\mathrm{b}}$ & $235.83 \pm 0.04^{\mathrm{e}}$ \\
P. linteus & $49.58 \pm 0.04^{\mathrm{a}}$ & $6.51 \pm 0.02^{\mathrm{a}}$ & $346.73 \pm 0.07^{\mathrm{b}}$ \\
P. astreatus & $33.11 \pm 0.07^{\mathrm{f}}$ & $5.30 \pm 0.01^{\mathrm{c}}$ & $256.05 \pm 0.10^{\mathrm{d}}$ \\
F. fomentarius & $28.74 \pm 0.05^{\mathrm{g}}$ & $4.66 \pm 0.01^{\mathrm{d}}$ & $215.60 \pm 0.15^{\mathrm{g}}$ \\
G. lucidum & $34.58 \pm 0.01^{\mathrm{e}}$ & $5.52 \pm 0.00^{\mathrm{b}}$ & $211.69 \pm 0.27^{\mathrm{h}}$ \\
P. eryngii & $38.92 \pm 0.06^{\mathrm{b}}$ & $5.61 \pm 0.02^{\mathrm{b}}$ & $289.97 \pm 0.11^{\mathrm{c}}$ \\
F. velutipes & $35.54 \pm 0.04^{\mathrm{c}}$ & $6.41 \pm 0.02^{\mathrm{a}}$ & $391.74 \pm 0.14^{\mathrm{a}}$ \\
L. edodes & $34.93 \pm 0.02^{\mathrm{d}}$ & $5.57 \pm 0.00^{\mathrm{b}}$ & $226.69 \pm 0.12^{\mathrm{f}}$ \\
\hline
\end{tabular}

${ }^{1}$ Values are mean $\pm \mathrm{SD}(\mathrm{n}=3)$. Means with the same letter in each row are not significantly different by Ducan's multiple range test $(\mathrm{p}<0.05)$.

담자균 배양 황기의 환원당 함량 측정

담자균 배양 황기의 환원당 함량을 측정한 결과 균주에 따른 함량 차이를 보였으며 결과는 Table 1 과 같다. 대조구 의 환원당 함량은 $235.83 \mathrm{mg} / 100 \mathrm{~g}$ 으로 나타났고, 팽이버섯 균사체 배양 황기는 $391.74 \mathrm{mg} / 100 \mathrm{~g}$ 으로 대조구에 비하여 약 2 배 높은 환원당 함량을 나타냈고, 상황버섯 균사체 및 큰 느타리 버섯균사체 배양 황기 또한 각각 $346.73 \mathrm{mg} / 100$ $\mathrm{g}, 289.97 \mathrm{mg} / 100 \mathrm{~g}$ 으로 높은 환원당 함량을 나타내었다. 
이러한 결과는 담자균이 생성한 a-amylase 효소 작용으로 인해 황기의 환원당 함량이 증가 한 것으로 사료되며, Park 등(18)의 연구결과에 의하면 곡물에 배양한 담자균들의 효 소활성이 배양기간이 지남에 따라 효소활성이 증가되고, 이러한 a-amylase 생성 미생물들이 발효식품 제조에서 전 분질 원료를 당화시키는 것으로 보고되며, amylose 가수분 해 효소인 fungamyl 처리에 의해 황기의 환원당 함량이 시간이 지남에 따라 증가한 보고(19)와 유사한 결과를 나타 내었다. 그러나 이외 말굽버섯, 영지버섯 및 표고버섯 균사 체 배양 황기는 각각 $215.60 \mathrm{mg} / 100 \mathrm{~g}, 211.69 \mathrm{mg} / 100 \mathrm{~g}$, $226.69 \mathrm{mg} / 100 \mathrm{~g}$ 으로 대조구에 비해 감소한 환원당 함량을 나타내었다.

Table 2. Extraction yields of Astragalus membranaceus fermented with diffeent mushroom mycelia

\begin{tabular}{lcc}
\hline \multirow{2}{*}{ Strains } & \multicolumn{2}{c}{ Yield (\%) } \\
\cline { 2 - 3 } Control & $80 \%$ EtOH extract & Water extract \\
P. linteus & $33.60 \pm 0.10^{1)}$ & $40.80 \pm 0.11$ \\
P. ostreatus & $20.00 \pm 0.09$ & $36.00 \pm 0.11$ \\
F. fomentarius & $27.20 \pm 0.11$ & $33.60 \pm 0.09$ \\
G. lucidum & $32.80 \pm 0.10$ & $32.80 \pm 0.12$ \\
P. eryngii & $25.60 \pm 0.11$ & $45.60 \pm 0.09$ \\
F. velutipes & $28.00 \pm 0.08$ & $52.00 \pm 0.10$ \\
L. edodes & $32.80 \pm 0.12$ & $41.60 \pm 0.11$ \\
\hline
\end{tabular}

${ }^{1)}$ Values are mean $\pm \mathrm{SD}(\mathrm{n}=3)$.

추출용매에 따른 추출수율

담자균 7종이 배양된 황기에 대한 $80 \%$ 에탄올 용매와 열수 추출에 대한 추출수율을 조사한 결과는 Table. 2 와 같다. 추출수율은 열수추출물이 $80 \%$ 에탄올 추출물 보다
높았으며, 열수 추출물의 경우 큰 느타리버섯 균사체 배양 황기가 $52 \%$ 로 가장 높은 수율을 나타낸 반면 이외 균사체 배양 황기의 추출수율은 32 45.6\%로 대조구에 비하여 높 거나 낮은 균주별로 상이한 결과를 나타냈다. $80 \%$ 에탄올 추출물의 추출수율은 모든 실험구에서 대조구보다 낮은 $33 \%$ 미만 이였으며, 특히 상황버섯균사체 배양 황기의 $80 \%$ 에탄올 추출물의 경우 $20 \%$ 로 가장 낮았다. 이러한 결과는 $\operatorname{Kim}$ 등(15)이 연구한 눈꽃 동충하초 균사체를 이용 한 백련잎의 고상발효과정을 통해 열수추출물의 수득율을 약 1.6 배정도 증가시켰고, 발효과정에 따른 용매별 추출수 율이 상반된 결과를 나타낸 것과 유사한 결과를 가지는 것을 알 수 있었다.

\section{담자균 배양 황기의 유리당 함량 분석}

담자균 배양 황기의 추출용매에 따른 유리당 함량을 측 정한 결과는 Table 3.과 같다. 담자균 무 접종 황기 즉, 대조 구의 $80 \%$ 에탄올 추출물은 fructose $1,260.85 \mathrm{mg} / 100 \mathrm{~g}$, glucose $1,199.83 \mathrm{mg} / 100 \mathrm{~g}$, sucrose $7,807.30 \mathrm{mg} / 100 \mathrm{~g}$ 이 검출되었다. 담자균이 배양된 황기의 $80 \%$ 에탄올 추출물의 경우 전반적으로 fructose 와 sucrose의 함량이 약 1.2 2배 증가하였는데 그 중 fructose는 큰 느타리버섯 균사체 배양 황기가 $2,154.61 \mathrm{mg} / 100 \mathrm{~g}$ 으로 크게 증가하였고, sucrose는 표고버섯 균사체 배양물이 $8,929.60 \mathrm{mg} / 100 \mathrm{~g}$ 으로 가장 크 게 증가하였다. 반면 glucose는 대조구에 비하여 감소하거 나 검출되지 않았다. 열수추출물에서 대조구의 유리당 함 량은 fructose $1,166.04 \mathrm{mg} / 100 \mathrm{~g}$, sucrose $9,324.40 \mathrm{mg} / 100$ $\mathrm{g}$ 이나, glucose의 경우 검출되지 않았다. 담자균이 배양된 황기의 열수추출물에서 fructose는 큰 느타리버섯 균사체 배양 황기가 $1,528.03 \mathrm{mg} / 100 \mathrm{~g}$ 으로 증가한 반면 glucose 및 sucrose는 대부분 감소하거나 검출되지 않았으나, 대조 구 자체에서 검출되지 않았던 glucose가 상황버섯 균사체 배양 황기에서 $1,547.51 \mathrm{mg} / 100 \mathrm{~g}$ 으로 검출되었다. Lee 등

Table 3. Free sugar contents of Astragalus membranaceus fermented with different mushroom mycelia

\begin{tabular}{lcccccc}
\hline & \multicolumn{3}{c}{ Contents $(\mathrm{mg} / 100 \mathrm{~g})$} \\
\cline { 2 - 6 } & Strains & \multicolumn{3}{c}{$80 \%$ EtOH extract } & Water extract \\
\cline { 2 - 6 } & Fructose & Glucose & Sucrose & Fructose & Glucose & Sucrose \\
\hline Control & $1260.85 \pm 0.14^{\mathrm{fl})}$ & $1199.83 \pm 0.19^{\mathrm{a}}$ & $7807.30 \pm 0.14^{\mathrm{d}}$ & $1166.04 \pm 0.03^{\mathrm{d}}$ & $\mathrm{ND}$ & $9324.40 \pm 0.05^{\mathrm{a}}$ \\
P. linteus & $854.61 \pm 0.10^{\mathrm{h}}$ & $929.26 \pm 0.13^{\mathrm{e}}$ & $\mathrm{ND}$ & $484.60 \pm 0.08^{\mathrm{h}}$ & $1547.51 \pm 0.08$ & $\mathrm{ND}$ \\
P. ostreatus & $1798.58 \pm 0.15^{\mathrm{c}}$ & $\mathrm{ND}^{2)}$ & $6591.35 \pm 0.19^{\mathrm{f}}$ & $1169.97 \pm 0.07^{\mathrm{c}}$ & $\mathrm{ND}$ & $6638.01 \pm 0.10^{\mathrm{f}}$ \\
F. fomentarius & $1065.18 \pm 0.06^{\mathrm{g}}$ & $\mathrm{ND}$ & $5991.62 \pm 0.14^{\mathrm{g}}$ & $941.46 \pm 0.10^{\mathrm{g}}$ & $\mathrm{ND}$ & $9149.86 \pm 0.12^{\mathrm{b}}$ \\
G. lucidum & $1306.49 \pm 0.11^{\mathrm{e}}$ & $\mathrm{ND}$ & $7865.18 \pm 0.15^{\mathrm{c}}$ & $1132.74 \pm 0.12^{\mathrm{e}}$ & $\mathrm{ND}$ & $8601.92 \pm 0.08^{\mathrm{d}}$ \\
P. eryngii & $2154.61 \pm 0.15^{\mathrm{a}}$ & $1109.73 \pm 0.05^{\mathrm{c}}$ & $7110.74 \pm 0.08^{\mathrm{e}}$ & $1528.03 \pm 0.06^{\mathrm{a}}$ & $\mathrm{ND}$ & $6154.98 \pm 0.04^{\mathrm{g}}$ \\
F. velutipes & $2030.89 \pm 0.10^{\mathrm{b}}$ & $1173.39 \pm 0.13^{\mathrm{b}}$ & $8432.01 \pm 0.11^{\mathrm{b}}$ & $1232.11 \pm 0.02^{\mathrm{b}}$ & $\mathrm{ND}$ & $6935.48 \pm 0.09^{\mathrm{e}}$ \\
L. edodes & $1417.12 \pm 0.13^{\mathrm{d}}$ & $999.62 \pm 0.21^{\mathrm{d}}$ & $8929.60 \pm 0.14^{\mathrm{a}}$ & $1091.65 \pm 0.19^{\mathrm{f}}$ & $\mathrm{ND}$ & $8691.36 \pm 0.20^{\mathrm{c}}$ \\
\hline
\end{tabular}

\footnotetext{
${ }^{1)}$ Values are mean $\pm \mathrm{SD}(\mathrm{n}=3)$. Means with the same letter in each row are not significantly different by Ducan's multiple range test $(\mathrm{p}<0.05)$.
}

${ }^{2)} \mathrm{ND}$, not detected. 
(20)의 보고에 의하면 균사체의 amylase분해효소에 의해서 glucose 등과 같은 환원당으로 분해되어져 발효의 기질로 이용되어 진다고 보고되었다. 그러나 본 실험에서 에탄올

Table 4. Major isoflavonoid contents of Astragalus membranaceus fermented with different mushroom mycelia

\begin{tabular}{lcccc}
\hline \multirow{3}{*}{ Strains } & \multicolumn{4}{c}{ Contents (mg/g, dry weight) } \\
\cline { 2 - 5 } & \multicolumn{2}{c}{$80 \%$ EtOH extract } & \multicolumn{2}{c}{ Water extract } \\
\cline { 2 - 5 } Colycosin & Formononetin & Calycosin & Formononetin \\
\hline Control & $732.15 \pm 0.10^{\mathrm{d} 1)}$ & $605.75 \pm 1.70^{\mathrm{d}}$ & $272.74 \pm 1.08^{\mathrm{g}}$ & $103.03 \pm 0.10^{\mathrm{f}}$ \\
P. linteus & $2549.24 \pm 2.27^{\mathrm{a}}$ & $1366.69 \pm 1.17^{\mathrm{a}}$ & $827.66 \pm 0.60^{\mathrm{a}}$ & $221.28 \pm 0.18^{\mathrm{a}}$ \\
P. ostreatus & $691.32 \pm 1.30^{\mathrm{f}}$ & $576.45 \pm 0.59^{\mathrm{e}}$ & $285.21 \pm 0.82^{\mathrm{f}}$ & $122.29 \pm 0.78^{\mathrm{d}}$ \\
F. fomentarius & $646.02 \pm 1.09^{\mathrm{g}}$ & $500.24 \pm 0.37^{\mathrm{g}}$ & $291.23 \pm 1.39^{\mathrm{e}}$ & $115.44 \pm 1.56^{\mathrm{e}}$ \\
G. lucidum & $702.87 \pm 2.85^{\mathrm{e}}$ & $568.02 \pm 0.70^{\mathrm{f}}$ & $273.95 \pm 0.72^{\mathrm{g}}$ & $120.19 \pm 1.02^{\mathrm{d}}$ \\
P. eryngii & $702.62 \pm 1.89^{\mathrm{e}}$ & $619.63 \pm 1.68^{\mathrm{c}}$ & $303.34 \pm 1.07^{\mathrm{d}}$ & $128.78 \pm 0.58^{\mathrm{c}}$ \\
F. velutipes & $983.57 \pm 1.47^{\mathrm{b}}$ & $744.14 \pm 1.99^{\mathrm{b}}$ & $328.36 \pm 1.22^{\mathrm{c}}$ & $127.64 \pm 0.58^{\mathrm{c}}$ \\
L. edodes & $788.29 \pm 0.83^{\mathrm{c}}$ & $621.22 \pm 1.58^{\mathrm{c}}$ & $349.45 \pm 0.64^{\mathrm{b}}$ & $142.35 \pm 1.18^{\mathrm{b}}$ \\
\hline
\end{tabular}

${ }^{1)}$ Values are mean $\pm \mathrm{SD}(\mathrm{n}=3)$. Means with the same letter in each row are not significantly different by Ducan's multiple range test $(\mathrm{p}<0.05)$.
추출물과 열수추출물의 유리랑 함량은 균사체별로 차이를 보였는데, 이는 추출용매 및 담자균 종류에 따라 유리당 총량 및 구성비 차이가 있으므로 균사체의 당 이용성에 차이가 나므로 상이한 결과를 나타낸 것으로 보여 진다 $(17,21)$.

\section{담자균 배양 황기의 성분 함량 분석}

담자균 무 접종 황기와 담자균 균사체 7종을 배양한 황기 의 추출용매에 따른 성분 함량을 측정하였다. 황기에 존재 하는 생리활성 물질로는 isoflavonoids성분으로 formononetin, calycosin 및 calycosin 7-O- $\beta-D$-glucoside, triterpenoids성분으 로 saponin류로서 astragalosides, polysaccarides 등이 알려져 있으 며 그 밖에 다양한 성분들이 포함되어 있는 것으로 보고된 바 있다(22). 본 실험에서는 황기의 지표성분으로 주요활성 성분이면서 함량이 비교적 높은 2 종의 성분 calycosin 및 formononetin을 HPLC 분석을 통해 확인(23)하였고 함량을 Table 4에 나타내었으며, HPLC 크로마토그램은 Fig. 1 및 Fig. 2에 나타내었다. 분석결과 대조구의 $80 \%$ 에탄올 추출 물은 calycosin이 $732.15 \mathrm{mg} / \mathrm{g}$, formononetin이 $605.75 \mathrm{mg} / \mathrm{g}$ 의 함량을 나타냈고, 열수추출물은 calycosin이 272.74
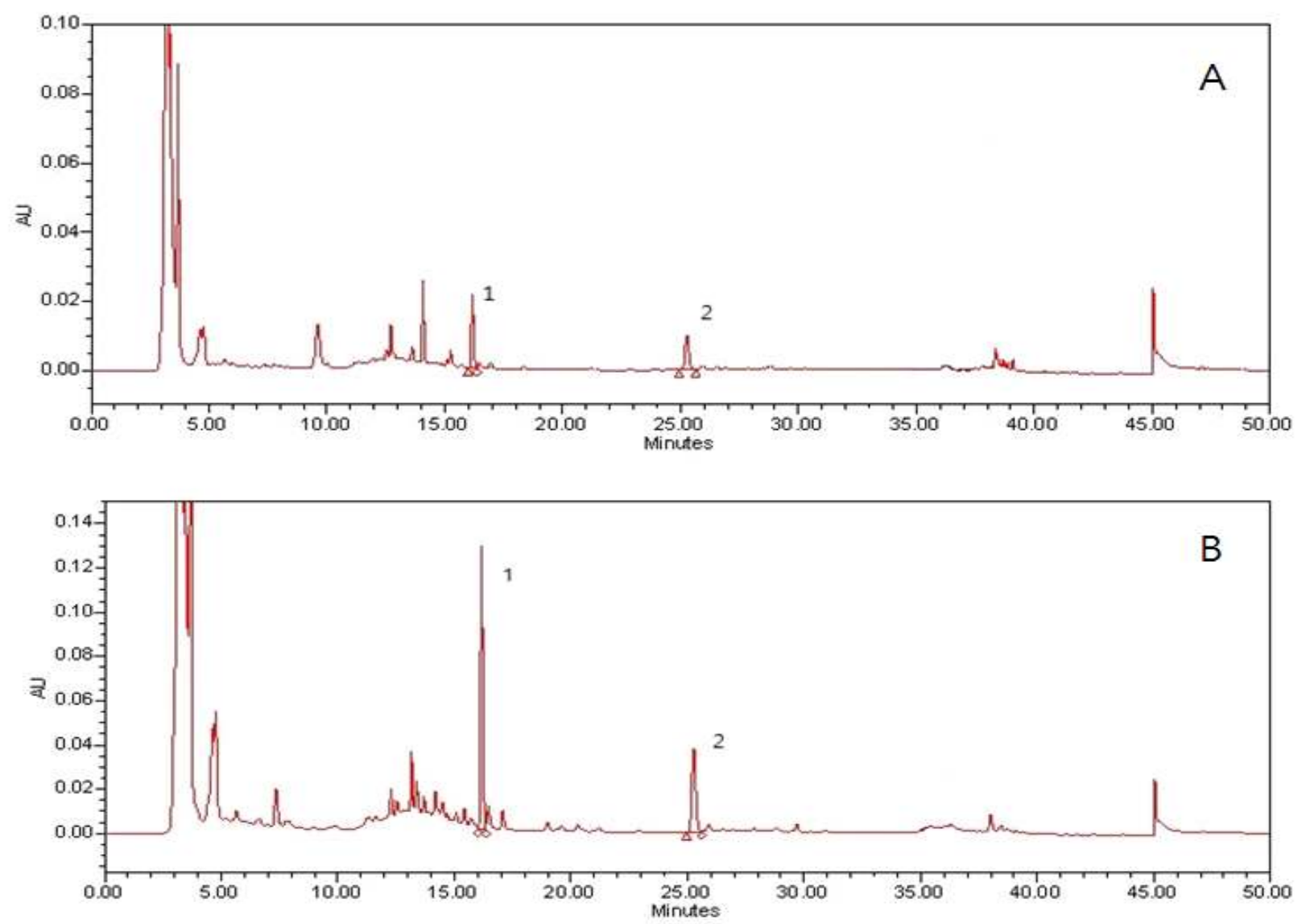

Fig. 1. HPLC chromatograms of the $80 \%$ ethanol extracts of Astragalus membranaceus fermented with different mushroom mycelia. A, $80 \% \mathrm{EtOH}$ extract of control; B, $80 \% \mathrm{EtOH}$ extract of Astragalus membranaceus fermented with P. linteus. 1, calycosin; 2, formononetin. 

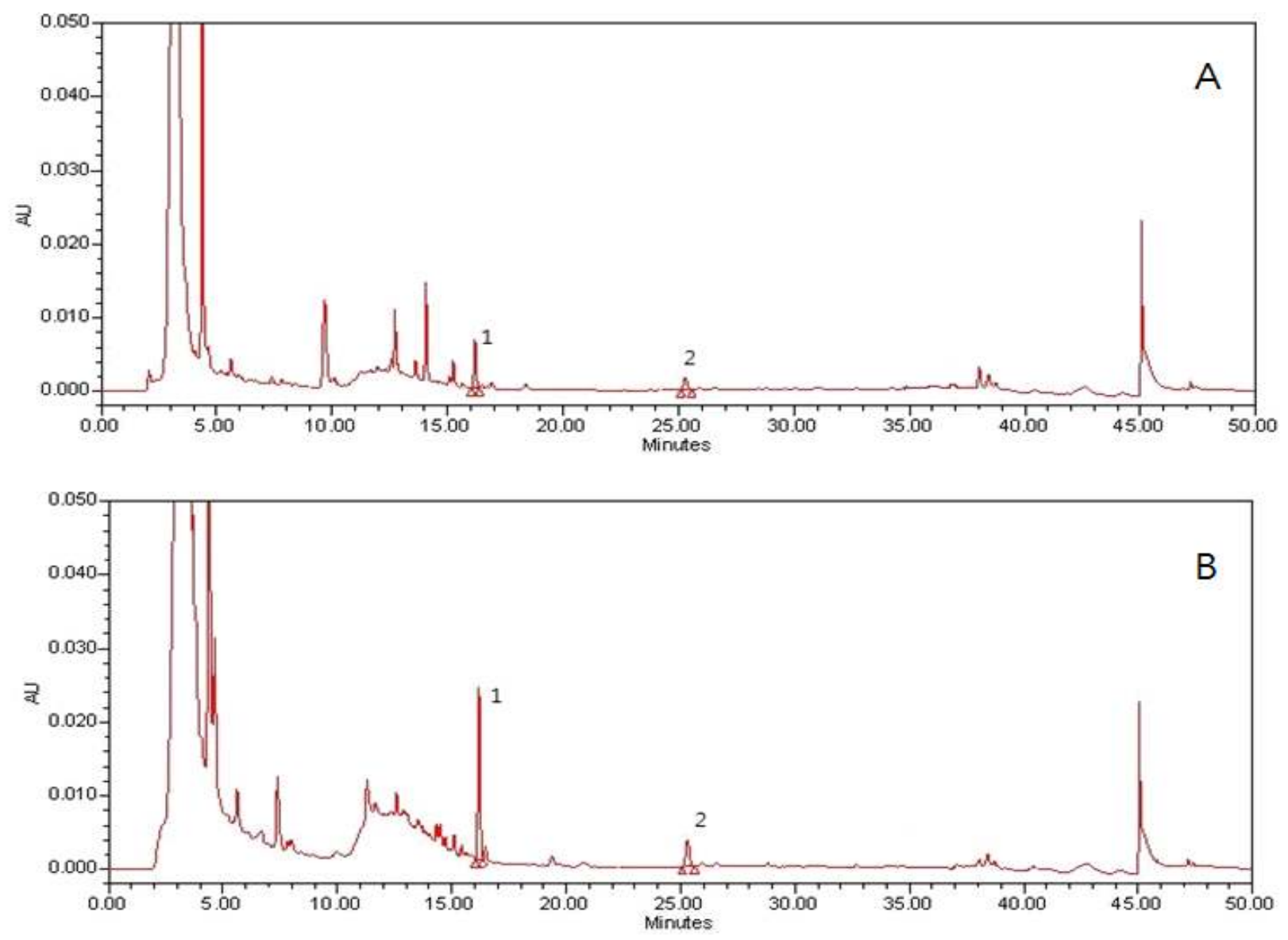

Fig. 2. HPLC chromatograms of the water extracts of Astragalus membranaceus fermented with different mushroom mycelia. A, water extract of control; B, water extract of Astragalus membranaceus fermented with P. linteus. 1, calycosin; 2, formononetin.

$\mathrm{mg} / \mathrm{g}$, formononetin이 $103.03 \mathrm{mg} / \mathrm{g}$ 의 함량을 나타내었다. 균사체 배양 황기를 분석한 결과 상황버섯 균사체로 배양한 황기의 $80 \%$ 에탄올 추출물의 calycosin 및 formononetin 함량이 $2,549.24 \mathrm{mg} / \mathrm{g}, 1,366.69 \mathrm{mg} / \mathrm{g}$ 으로 대조구에 비해 각각 3.5 배와 2.3 배 증가한 함량으로 다른 균사체 배양 황기 보다 유의적으로 높은 함량을 나타내었다. 더불어 열수추 출물 또한 상황버섯 균사체로 배양한 황기의calycosin 및 formononetin 함량이 각각 $827.66 \mathrm{mg} / \mathrm{g}, 221.28 \mathrm{mg} / \mathrm{g}$ 으로 대조구 보다 높은 함량을 나타내었다. 팽이버섯 균사체로 배양한 황기의 $80 \%$ 에탄올 추출물의 함량은 calycosin $983.57 \mathrm{mg} / \mathrm{g}$, formononetin $744.14 \mathrm{mg} / \mathrm{g}$ 이고, 열수추출물은 calycosin $328.36 \mathrm{mg} / \mathrm{g}$, formononetin $221.28 \mathrm{mg} / \mathrm{g}$ 으로 증가 한 함량을 나타내었고, 표고버섯 균사체로 배양한 황기의 열수추출물 함량도 calycosin $349.45 \mathrm{mg} / \mathrm{g}$, formononetin $142.35 \mathrm{mg} / \mathrm{g}$ 으로 증가한 것을 알 수 있었다. 이는 황기에는 calycosin 및 formononetin의 배당체를 많이 함유하고 있는 데 이러한 배당체형태의 성분들인 calycosin 7-O- $\beta$

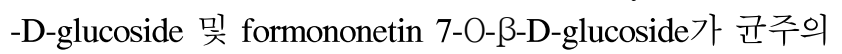
효소분해 작용으로 인해 비 배당체 형태인 calycosin 및 formononetin으로 전환되어 함량이 증가한 것으로 사료되 며, 이는 당분해효소를 이용하여 배당체 형태의 황기 성분 을 aglycon형태로 전환한 연구결과(23)및 유산균 발효를 통해 자음강화탕의 배당체 성분인 nodakenin을 aglycon인 nodakenitine으로 전환시킨 보고(24)와 유사하였다. 이러한 황기의 대표적인 isoflavonoids 성분인 calycosin 및 formononetin은 항산화, 항염증 효능 및 면역증진 활성 등 의 다양한 생리활성 효능이 보고 되어져(25-27) 있는데, 배 당체 형태로 존재하여 체내 흡수, 이용률 저하 등 미비한 효과를 나타내는 성분들을 균사체 배양 발효공정을 통해 미생물의 효소를 이용하여 유기물을 분해 및 변화 시킬 뿐만 아니라 활성성분의 생물전환을 일으켜 체내흡수율과 생체 이용율을 증진 시키므로 식품산업 등 여러모로 폭넓은 이용 가능성이 있을 것으로 사료된다 $(28,29)$.

\section{요 약}

본 연구에서는 담자균 균사체를 황기에 배양하여 이용성 
및 기능성을 증진시킨 식품 및 소재를 개발하기 위한 연구 의 일환으로 기초연구를 실시하였다. 수분함량, $\mathrm{pH}$ 및 환원 당을 측정함으로서 균사체 배양 황기의 변화를 관찰한 결과 수분함량은 대조구에 비하여 전체적으로 증가하였으며, $\mathrm{pH}$ 는 상황버섯 균사체 및 팽이버섯 균사체 배양 황기의 $\mathrm{pH}$ 가 각각 $6.51,6.41$ 로 증가하는 경향을 보였으나, 이 외의 균사체가 배양된 황기는 대조구와 유사한 수치인 $\mathrm{pH}$ 5.30 5.61로 미미하거나 특별한 변화폭을 보이지 않았다. 환원당 함량 측정결과 팽이버섯 균사체 배양 황기가 대조구 에 비해 약 2 배 증가한 $391.74 \mathrm{mg} / 100 \mathrm{~g}$ 으로 가장 높은 함량을 나타냈고, 다음으로 상황버섯 및 큰 느타리버섯 균 사체 배양 황기가 각각 $346.73 \mathrm{mg} / 100 \mathrm{~g}$ 및 $289.97 \mathrm{mg} / 100$ $\mathrm{g}$ 으로 다소 증가한 함량을 나타냈다. 추출용매에 따른 균사 체 배양 황기의 추출수율 결과 열수추출물이 $80 \%$ 에탄올 추출물 보다 높았으며, 큰 느타리버섯 균사체 배양 황기의 열수추출물이 $52 \%$ 로 가장 높은 수율을 나타내었다. 유리당 함량 분석결과 $80 \%$ 에탄올 추출물에서 fructose는 큰 느타 리버섯 균사체 배양 황기의 함량이 $2,154.61 \mathrm{mg} / 100 \mathrm{~g}$ 으로 가장 높았고, sucrose는 표고버섯 균사체 배양 황기가 $8,929.60 \mathrm{mg} / 100 \mathrm{~g}$ 으로 가장 높은 함량을 보였으며, glucose 는 모든 실험구에서 감소되거나 검출되지 않았다. 열수추 출물에서 fructose는 $1,528.03 \mathrm{mg} / 100 \mathrm{~g}$ 으로 큰 느타리버섯 균사체 배양 황기가 가장 높은 함량을 나타낸 반면 glucose 및 sucrose는 전반적으로 감소되거나 검출되지 않았다. 그 러나 대조구 자체에서 검출되지 않았던 glucose가 상황버섯 균사체 배양 황기에서 $1,547.51 \mathrm{mg} / 100 \mathrm{~g}$ 의 높은 함량으로 검출되었다. 담자균 배양 황기의 성분 함량을 분석한 결과 $80 \%$ 에탄올 추출물에서 상황버섯(calycosin $2,549.24 \mathrm{mg} / \mathrm{g}$, formononetin $1,366.69 \mathrm{mg} / \mathrm{g}$ ) > 팽이버섯(calycosin 983.57 $\mathrm{mg} / \mathrm{g}$, formononetin $744.14 \mathrm{mg} / \mathrm{g}$ ) > 표고버섯(calycosin $788.29 \mathrm{mg} / \mathrm{g}$, formononetin $621.22 \mathrm{mg} / \mathrm{g}$ ) 순으로 함량이 크 게 증가하였고, 열수추출물에서는 상황버섯(calycosin $827.66 \mathrm{mg} / \mathrm{g}$, formononetin $221.28 \mathrm{mg} / \mathrm{g}$ ) > 표고버섯 (calycosin $349.45 \mathrm{mg} / \mathrm{g}$, formononetin $142.35 \mathrm{mg} / \mathrm{g}$ ) > 팽이버 섯(calycosin $328.36 \mathrm{mg} / \mathrm{g}$, formononetin $127.64 \mathrm{mg} / \mathrm{g}$ ) 순으 로 높은 함량은 나타내었다. 이러한 결과는 담자균의 효소 활성으로 인해 황기의 배당체 성분이 aglycon형태로 전환 됨으로서 calycosin 및 formononetin 함량이 증가한 것으로 사료된다. 본 연구에서 담자균 균사체 배양을 통해 황기의 기능성을 증대 시킬 수 있음을 알 수 있었고, 이러한 담자균 이 배양된 황기를 이용하여 기능성 및 생리활성 효능 등이 증대된 식품소재 및 건강기능식품으로 개발 가능성이 있음 을 제시하였다. 따라서 본 연구결과를 기초자료로 하여 황 기의 기능성을 증대시키기에 적합한 담자균을 이용하여 배양일에 따른 황기의 이화학적 특성 및 성분분석과 더불어 세포실험 등을 통해 기대되는 생리활성 효능에 대한 검증이 필요할 것으로 생각된다.

\section{감사의 글}

본 연구는 농촌진흥청 국립농업과학원 농업과학기술 연 구사업(과제번호: PJ01012202)의 지원에 의해 이루어진 것 이며 이에 감사드립니다.

\section{References}

1. Morita K, Hara M, Kada T (1978) Studies on natural desmutagens: screening for vegetable and fruit factors active in inactivation of mutagenic pyrolysis products from amino acid. Agri Biol Chem, 42, 1235

2. Jung IC, Kim SH, Kwon YI, Lee JS (1996) Cultural condition for the mycelial growth of Ganoderma lusidum on cereals. Korean J Mycol, 24, 81-88

3. Baek NI, Kim YS, Kyung JS, Park KH (1996) Isolation of and hepatotoxic from the root of Astragalus membranceus. Korean J Pharmacogn, 27, 111-116

4. Jung HS, Lee EJ, Kim JS, Kang SS (2008) Phytochemical studies on Astragalus membranceus root (3): Triterpenoids and sterols. Korean J Pharmacogn, 39, 186-193

5. Ryu MS, Kim EH, Chun MS, Kang SH, Shim BS, Yu YB, Jeong GJ, Lee JS (2008) Astragali Radix elicits anti-inflammation via activation of MKP-a, concomitant with attenuation of p38 and Erk. J Ethnopharmacol, 115, 184-193

6. Inoue K, Shirai T, Ochiai H, Kasao M, Hayakawa K, Kimura M (2003) Blood-pressure-lowering effect of a novel fermented milk containing 8 -aminobutyric acid in mild hypertensives. Eur J Clin Nutr, 57, 490-495

7. Yin Y, Heo SI, Jung MJ, Wang MH (2009) Antioxidant and antidiabetic effects of various sections of Astragalus membranaceus. Korean J Pharmacogn 40, 1-5

8. Ahn DK (1992) Medicinal fungi in Korea. Korean J Mycol, 20, 154-166

9. Toth JO, Luu B, Ourisson G (1983) Triterpenes cytotoxiques de Ganoderma lucidum (Polyporaceae). Tetrahedron Letters, 24, 1081-1084

10. Jung IC, Kim SH, Kwon YI, Kim SY, Lee JS, Park S, Park KS, Lee JS (1997) Cultural condition for the mycelial growth of Phellinus igniarius on chemically defined medium and grains. Korean J Mycol, 25, 133-142

11. Han SY, Shon MY, Lee SW (2003) Physiological activities of mycelial Flammulina velutipes cultured in liquid grain media. Korean Food Ind Nutr, 8, 50-56 
12. Jung IC (2006) Manufacturing and sensory characteristics of Jupjang using grains fermented by Basidiomycetes. Korean J Food Cookery Sci, 22, 337-345

13. Choi HD, Seong HM, Park YK, Kim JA (2007) Hypoglycemic effects of Basidiomycetes mycelia and cereals fermented with Basidiomycetes. J Korean Soc Food Sci Nutr, 36, 1257-1262

14. Kim DS, Roh JH, Cho CW, Ma JY (2012) Analysis of nodakenetin from Samultangs fermented by Lactose bactera strains. Korean J Herbol, 27, 35-9

15. Kim JS, Wang SB, Kang SK, Cho YS, Park SK (2009) Quality properties of white lotus leaf fermented by mycelial Paecilomyces japonica. J Korean Soc Food Sci Nutr, 38, 594-600

16. Park CS, Lee TS (2002) Quality characteristics of Takju prepared by wheat flour Nuruks. Korean J food Sci Technol, 34, 296-302

17. Kim SH, Lee JS, Park KS, Lee JS, Lee HW, Park S (1999) Liquid culture of Basidiomycetes on natural media. Korean J Mycol, 27, 373-377

18. Park HS, Kim BH, Choi HS, Kim JM, Kim MK (2010) Enzyme activity of Basidiomycetes products in each cereals. J Mushroom, 8, 102-108

19. Kwon SC, Choi GH, Hwang JH, Lee KH (2010) Physicochemical property and antioxidative activity of hot water extracts from enzyme hydrolysate of Astragalus membranaceus. J Korean Soc Food Sci Nutr, 39, 406-413

20. Lee H, Kim YS, Kim DY, Kim SY, Lee WK, Lee SM, Park JD, Shon MY (2015) A study on manufacturing of red ginseng Makgeolli using the red ginseng starch and changes of physicochemical components of red ginseng Makgeolli during storage periods. Korean J Food Preserv, 22, 369-376

21. Jung IC, Ha HC, Kwak HJ (2002) Comparison of free sugar content in grains fermented with mycelia of the Basidiomycetes. J Applied Tourism Food Beverage Management Research, 13, 69-80

22. Guo JK (1996) International coalition of traditional and folk medicine. Kumara T, ed. World Scientific Publisher, Singapore, p 1-16

23. Im KR, Kim MJ, Jung TK, Yoon KS (2010) Analysis of isoflavonoid contets in Astragalus membranaceus bunge cultivated in different areas and at various ages. KSBB J, 25, 271-276

24. Lee KJ, Song NY, Roh JH, Liang C, Ma JY (2013) Analysis of bioconversed-components in fermented Jaeumganghwa-tang by Lactobacillus. J Appl Biol Chem,
56, 131-135

25. Fan Y, Wu DZ, Gong YQ, Zhou JY, Hu ZB (2003) Effects of calycosin on the impairment of barrier function induced by hypoxia in human umbilical vein endothelial cells. Eur J Pharmacol, 14, 33-40

26. Zhang WJ, Hufnagl P, Binder BR, Wojta J (2003) Antiinflammatory activity of astragaloside IV is mediated by inhibition of NF-Kappa B activation and adhesion molecule expression. Thrombosis Haemostasis, 90, 904-914

27. Du XG, Z hao B, Li JY, Cao XH, Diao MK, Feong HB, Chen XB, Cheon ZY, Zeong XY (2012) Astragalus polysaccharides enhance immune responses of $\mathrm{HBV}$ DNA vaccination via promoting the dendritic cell maturaion and suppressing Treg frequency in mice. International Immunopharmacology, 14, 463-470

28. Bae EA, Han MJ, Kim EJ, Kim DH (2004) Transformation of gingeng saponins to ginsenoside $\mathrm{Rh} 2$ by acids and human intestinal bacteria and biological activities of their transformants. Arch Pharm Res, 27, 61-7

29. Cho SI, Kim HW, Lee GJ (2006) Biological activites of extracts of fermented Camellia japonica leaf and flower. Korean J Herbol, 21, 55-62

30. Goh EJ, Seong ES, Lee JG, Na JK, Lim JD, Kim MJ, Kim NY, Lee GH, Seo JS. Cheoi DS, Chung IM, Yu CY (2009) Antioxidant activities according to peeling and cultivated years of Astragalus membranaceus roots. Korean J Med Crop Sci, 17, 233-237

31. Hwang JB, Yang MO, Shin HY (1998) Survey for amino acid of medicinal herbs. Korean J Food Sci Technol, 30, 35-41

32. Park CS, Kim DH, Kim ML (2008) Biological activities of extracts from corni fructus, Astragalus membranaceus and Glycyrrhiza uralensis. Korean J Herbology, 23, 93-101

33. Cho YS, Park SK, Lee KS, Kim JY, Wang SB, Shon MY (2008) Development of microbial fermented tea using wild type green tea. Report of technology development program for agriculture and forestry, Ministry for Agriculture, Forestry and Fisheries. Seoul, Korea, p 173

34. Han SH, Woo NRY, Lee SD, Kang MH (2006) Antioxidative and antibacterial activities of endemic plants extract in Korea. Korean J Med Crop Sci, 14, 49-55 